\title{
SIR RONALD ROSS, MALARIA, AND THE REWARDS OF RESEARCH
}

\author{
by \\ ELI CHERNIN*
}

\section{INTRODUCTION}

In 1897-98, while a young surgeon in the Indian Medical Service (IMS), Ronald Ross incriminated mosquitoes in malaria transmission, a remarkable piece of research considering that he did not know what he was looking for in his mosquitoes or even if they were the "right" insects. ${ }^{1}$ His main guidance came from Patrick Manson, who had hypothesized that mosquitoes might be the culprits. The research in India was beset by bureaucratic bunglings within the IMS, and by Ross's want of scientific training; both were offset by the prodigies of work that would also characterize Ross's later undertakings. In apparent self-description, written years after India, Ross said that "Medical discovery, like all discovery, requires two rather rare qualities - an acute instinct for the right direction, and a burning perseverance in following it up."2 Ross's mosquito-malaria work capped his eighteen-year career in the IMS, and brought him the Nobel Prize in 1902.

Ross's achievement in India entrained less familiar involvements that are the concern of the present study: specifically, his seeking after monetary reward for his research from Britain and her institutions. Ross's efforts to gain the rewards of research went unrequited, although they occupied his attention for some thirty years, engaged the highest levels of British medicine, science, and government, and drew attention to the indifferent economic status of medical scientists.

\section{ROSS'S BACKGROUND}

Ross was born in India in 1857 during the Great Mutiny, and he died in London in 1932 during the Great Depression. While the mosquito-malaria work represented the apogee of Ross's career, he was also a mathematician, epidemiologist, sanitarian, editor, novelist, dramatist, poet, and an amateur musician, composer, and artist. His cerebral pursuits notwithstanding, Ross was at heart a doer, and impatient with those he regarded as intellectually palsied who obstructed him. Ross seemed abrasive, touchy, combative, arrogant, and unyielding. Men who knew Ross

*Eli Chernin, ScD, Professor of Tropical Public Health, Harvard University, Boston, Massachusetts 02115, USA.

${ }^{1}$ For a general description of Ross's research, see: Ronald Ross, Memoirs, London, John Murray, 1923,pp. 115-360. See also, P. Manson-Bahr, 'The story of malaria: the drama and the actors', Intl. Rev. Trop. Med., 1963, 2: 329-390; and G. Harrison, Mosquitoes, malaria and man, New York, E. P. Dutton, 1978, pp. 17-102.

${ }^{2}$ R. Ross, 'Thoughts on medical discovery', Sci. Prog., 1925, 19: 475. 


\section{Eli Chernin}

professionally describe the hostility he sometimes generated, ${ }^{3}$ but Ross was, however, said to be kind and supportive to junior colleagues, friends, and family. ${ }^{4}$

We may never grasp how Ross's complex personality emerged from his own genetics and Victorian upbringing, but the outlines of his life are well known. Ross came from a Scottish military family based in India, and, aged eight, he was sent to Britain for schooling at which he did not excel. His father, eventually a general in the Indian Army, urged a medical career upon him, and Ross - with no university degree entered St Bartholomew's Hospital in London, in 1874, where he managed indifferently. Ross qualified for the Royal College of Surgeons (MRCS) in 1879, but failed once before qualifying as a Licentiate of the Society of Apothecaries (LSA); in 1881 , with the credentials of a "surgeon-apothecary", he joined the IMS, again at his father's wish. The IMS usually made for "a serviceable if not brilliant career", 5 and while it produced several respected researchers in tropical medicine, none was of Ross's stature.

In 1894, when Ross was on leave in London, Patrick Manson showed him the parasites of human malaria that Laveran had discovered in 1880. Manson had found in 1878 that certain mosquitoes could serve as the intermediaries for the human filarial parasites, ${ }^{6}$ and he now hypothesized to Ross that malaria might also be mosquitoborne. Ross, then thirty-seven, returned to India, and with Manson's epistolary encouragement and advice, together with considerable labour, discomfort, and personal cost - and with self-admitted "supreme good luck"7 — uncovered the role of certain mosquitoes in transmitting malaria parasites.

Major Ross retired from the IMS in 1899, and accepted a lectureship, which Manson helped arrange, at the newly opened Liverpool School of Tropical Medicine. ${ }^{8}$ The dozen years Ross spent at Liverpool were a time of family, teaching, promotions, important medical expeditions to the tropics, and increasing friction with the School's administration. ${ }^{9}$ It was also a time of awards, notably election to the Royal Society in 1901, the Nobel Prize in 1902, and a knighthood (KCB) in 1911. During this time, another element appeared and persisted for the rest of Ross's life; a preoccupation with money and the rewards of research.

${ }^{3}$ H. H. Scott, A history of tropical medicine, London, Edward Arnold, 1939, vol. 2, p. 1089; also, Manson-Bahr, op. cit., note 1 above, p. 360.

${ }^{4}$ M. E. Gibson, 'Sir Ronald Ross and his contemporaries', J. R. Soc. Med., 1978, 71: 612; also, M. Watson, 'Ronald Ross, 1857-1932', Sci. Prog., 1933, 27: 390.

${ }^{5}$ M. J. Peterson, The medical profession in mid-Victorian London, Berkeley, University of California Press, 1978, p. 125.

${ }^{6}$ E. Chernin, 'Sir Patrick Manson's studies on the transmission of filariasis', Rev. inf. Dis., 1983,5: 148-166.

${ }^{7}$ R. Ross, 'Is discovery inevitable?', Sci. Prog., 1927, 22: 130.

8 The Liverpool and London Schools of Tropical Medicine were founded in 1899 on the initiatives of the Secretary of State for the Colonies, Joseph Chamberlain, and of Patrick Manson, who was Medical Adviser to the Colonial Office from 1897 to 1912. The Liverpool School depended for funds mainly on private sources and was thus less stable financially than the largely government-supported London School.

${ }^{9}$ M. E. Gibson, A catalogue of the Ross Archives, London School of Hygiene and Tropical Medicine, 1983 [text and microfiche], p. 16. 


\section{A BRITISH NOBEL PRIZE}

In 1906, Ross published an unsigned proposal for a British Nobel Prize, ${ }^{10}$ arguing that the British should not have to look to Sweden for reward, that fame did not educate a researcher's children or provide him a pension, and that the nation should not use a man's research for nothing; the proposed Prize would pay men who advanced medical science but received no monetary recompense for the work. Ross's plan for a British Nobel Prize failed to stir the medical community. He had, however, mentioned in his paper that in the early nineteenth century Parliament had voted Jenner $£ 30,000$ for developing vaccination. This type of reward seemed to appeal to Ross, for he wrote to a friend that "It occurred to me that I had better go to my lawyer and see what he suggested. After I told him about Jenner getting $£ 30,000$ from Parliament, he at once said that he thought a case might lie, if not on legal, yet on strong moral grounds."11 His lawyer's favourable reaction may have deflected Ross from further advocating the British Nobel Prize, and after a lapse of seven years Ross did, in fact, petition Parliament.

\section{THE LIVERPOOL PENSION}

Ross resigned from the Liverpool School in 1912, having decided to establish a consultant's practice in London. His salary at Liverpool had risen from $£ 250$ to $£ 300$ in 1899 , to $£ 600$ when he became Professor of Tropical Medicine in 1903, and to $£ 800$ in 1910. For an indeterminate period, Ross also received an unspecified "proportion of student fees" and a consultant's fee of $£ 100$ annually. ${ }^{12}$ In addition, $£ 292$ came to Ross annually as his IMS pension. Thus Ross's gross income during his first year at

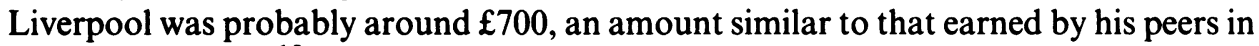
the United States. ${ }^{13}$

In 1918, six years after his move to London, the Liverpool School offered Ross an honorary Vice-Presidency, and he took the occasion to press the School for a pension, a matter he had not resolved earlier. In replying to Sir Francis Danson, Chairman of the School, Ross asserted that in 1899 the School's authorities had said they would try to arrange a pension for him, and thus he felt he still had a claim for one; accordingly, he asked Danson if accepting the Vice-Presidency would compromise his claim. ${ }^{14} \mathrm{At}$ the same time, Ross wrote to a friend: "Personally I care very little about a pension and would like for several reasons to do without ... On the other hand, if they do not give me one I shall certainly feel it my duty in the interests of science to show them up."15

10 'A British Nobel Prize', Brit.med.J., 1906, ii: 1667-1668. [Unsigned, but Ross privately identified himself as the author in a letter to Sir Alfred Keogh, 3 December 1906, RA 36/007]. Bibliographic note: Many references in this paper are drawn from the Ross Archives at the London School of Hygiene and Tropical Medicine. These references are designated "RA" followed by the Archives' file number. See Gibson, op. cit., note 9 above, for the catalogue to the Ross Archives.

${ }_{11}$ Ross to Sir Alfred Keogh, 18 December 1906, RA 36/012.

12 Ross, op. cit., note 1 above, pp. 370-371, 414, 511-513.

${ }^{13}$ The salaries, 1899-1900, of three prominent professors of medical science in the Harvard Medical School were: Theobald Smith $\$ 3,400$, Charles Sedgwick Minot, $\$ 3,000$, and Harold C. Ernst, $\$ 3,000$. From the Official Harvard Corporation Records for 1900, Harvard Archives, Cambridge.

${ }_{14}$ Ross to F. C. Danson, 10 September 1918, RA 33/349.

${ }^{15}$ Ross to A. H. Milne, 17 September 1918, RA 33/352. 


\section{Eli Chernin}

Danson soon informed Ross that the School's governing committee had denied his claim to a pension, ${ }^{16}$ whereupon Ross wrote to Lord Leverhulme, a former Chairman of the Liverpool School: "Of course I refuse to be a Vice-President of such a body. But I have not replied yet. I am like the monkey who, when he ate a flea, said, 'what must be endured should be enjoyed'."17 Ross informed Danson that he would not pursue matters further because he had no legal grounds for a claim, and he closed his letter and the dispute in typical Ross style: "I have never regretted leaving your service, and, under the circumstances, do not wish to continue the connection by accepting the post of Vice-President - which I presume you offered me in lieu of pension."18

THE INDIA PENSION

About to leave Liverpool in 1912, Ross asked the India Office "for one of the higher-scale pensions which are sometimes given to officers of the Indian Medical Service", pointing to his scientific accomplishments, their personal cost, and the meagre pension he had been receiving since retiring in $1899 .{ }^{19}$ The India Office in reply praised his work, but since Ross had voluntarily retired from the IMS, the Secretary of State for India could not accede to the request. ${ }^{20}$ Ross's response was uncharacteristically mild: "I was under the impression that such additional pensions were given for the good work done during service, and did not know that retirement under the rules of the service is any bar to the receipt of them."21

Ross explained less mildly to Sir William Lever (later the Lord Leverhulme referred to above) that he left India in 1899 "largely because all my cash had been spend [sic] upon running about all over the country and dragging my wife and family . . . in order to carry out the very investigation which the Secretary of State now commends."22 Ross thought it "insane" that men who carry out such investigations should receive no remuneration. He also sent copies of his India Office correspondence to Sir Thomas Barlow, President of the Royal Society of Medicine, saying that because of the India Office's refusal "I have been forced to resign my Professorship [at Liverpool] to take up practice in London." 23 Ross asserted to Sir Thomas that "the whole of tropical medicine is now being run on something very like the sweating [sweatshop] system", and he later told Barlow that it was not so much the pension itself that concerned him as the fact that men teaching and doing research in tropical medicine were being exploited. $^{24}$

${ }^{16}$ F. C. Danson to Ross, 18 November 1918, RA 33/362.

${ }_{17}^{17}$ Ross to Lord Leverhulme, 19 November 1918, RA 33/363.

${ }^{18}$ Ross to F. C. Danson, 2 December 1918, RA 33/367.

${ }^{19}$ Ross to India Office, 7 March 1912, RA 37/001.

${ }^{20}$ India Office to Ross, 3 April 1912, RA 37/002.

${ }^{21}$ Ross to India Office, 15 April 1912; Br. med. J., 1914, i: 457.

${ }^{22}$ Ross to Sir William Lever, 4 April 1912, RA 37/006.

${ }^{23}$ Ross to Sir Thomas Barlow, 30 October 1912, RA 37/008. Ross's explanation for moving to London is questionable if not disingenuous. It seems unlikely that failure to get the extra pension ( $£ 100$ p.a.) could have "forced" his move from Liverpool to London. According to his Memoirs (op. cit., note 1 above, p. 512), Ross had wished since 1899 to take up consulting practice in London. Furthermore, his move in 1912 coincided with Manson's retirement; Ross said he might have moved to London sooner but that he "did not wish to interfere with Dr. Manson's practice there." (Ibid., p. 369).

${ }^{24}$ Ross to Sir Thomas Barlow, 12 November 1912, RA 37/010. 


\section{Sir Ronald Ross, malaria, and the rewards of research}

In 1914 - about two years after the private exchanges - Ross published his India Office correspondence; ${ }^{25}$ the letters appeared with an unsigned but supportive note Ross drafted at the request of the editor of the British Medical Journal, Dawson Williams. ${ }^{26}$ Further attention came when Waldorf Astor put a question in the House of Commons concerning additional India pensions, ${ }^{27}$ and corresponded further about the matter with Ross. ${ }^{28}$

Before his India Office letters reached print, Ross published an invited paper recounting the contributions of the Liverpool School to tropical health. He condemned failure to provide adequate recompense to men who gave exceptional medical services to the empire, and he underscored the small salaries and pensions at the two schools of tropical medicine: "Numbers of lecturers receive nothing or next to nothing, and the payment of the junior posts no longer tempts the best men."29

Ross presently asserted in a published letter that "Science has become... the premier industry of the world", and that government owes payment for valuable research that carries no pecuniary advantage to the worker. ${ }^{30} \mathrm{~A}$ precedent for this, said Ross, was Parliament's giving Jenner money for his work, but in general the "mere utilization of work implies payment ... [and] this principle applies to nearly the whole of medical work, in which advice is almost always given without contract." Ross also asserted that the British Empire was "bound in honour" to pay the professional men who serve it well. Satisfying claims would do more, according to Ross, "to encourage science and to save human life and health than almost anything else can do. Of course, my position is that of an interested party, but that does not render the argument unsound" [italics added]. A correspondent wrote to support Ross: "[Since] nobody could add an acre to the land originally given us by the Creator ... I wonder how many acres Sir Ronald's discoveries have added to the map of the empire?"31

Ross now disclosed publicly that he had submitted a petition to Parliament for remuneration for his discoveries in malaria, and he urged other medical men with valid claims to follow his lead and petition. ${ }^{32}$

\section{ROSS PETITIONS PARLIAMENT}

After what he later characterized as his "thirteen pleasant years in Liverpool", 33 Ross moved in 1912 to a house in Cavendish Square,,$^{34}$ an exclusive section of London populated by wealthy physicians and other prominent figures. We do not know

\footnotetext{
25 [Unsigned note, attributed to Ross; see note 26] 'The reward of research in India', Br. med. J., 1914, i: $456-457$.

${ }^{26}$ Ross to Dawson Williams, 14 February 1914, RA 37/016.

27 Waldorf Astor to Ross, 26 March 1914, RA 37/022.

28 Ross to Waldorf Astor, 27 March 1914; RA 37/023.

${ }^{29}$ R. Ross, 'Tropical medicine - a crisis', Br. med. J., 1914, i: 319-321.

${ }^{30}$ Ross to Editor, ibid., p. 738.

${ }^{31}$ H. Faulds to Editor, ibid., p. 888.

${ }^{32}$ Ross to Editor, ibid., pp. 941-942.

33 Ross, op. cit., note 1 above, p. 511.

34 Ross lived and worked at 18 Cavendish Square from 1912 to 1918 , having purchased the lease of the house from Sir Francis Laking, Physician to the King (ibid., p. 512). In 1985, the Greater London Council placed a blue commemorative plaque on the house, and another, honouring Sir Patrick Manson, on a house nearby. See: Trans. R. Soc. Trop. Med. Hyg., 1985, 79: 656.
} 
whether Ross's new practice flourished or where he stood financially at this time. In July 1913, Ross became editor of Science Progress, an influential multidisciplinary quarterly review journal, and he remained its editor for the twenty years until his death. The editorship gave Ross a ready outlet for his prolific writings ${ }^{35}$ and it probably added to his reputation and status. Ross received a modest income from John Murray, the commercial publisher of Science Progress, amounting to half the profits from sales or roughly $£ 100$ per year. ${ }^{36}$

Ross's petition to Parliament, submitted in November 1913, has its first intimation in 1901 when Ross wrote to Sir Alfred Jones, Chairman of the Liverpool School, to solicit his support. The letter declared Ross's intention to "petition Government for a pecuniary reward" for his work on malaria. His studies, said Ross, not only cost him years of his life, "but also all my money, my prospects as a medical practitioner, and, I feel, a large part of my health", and he and his family could depend only on his IMS pension should he become incapacitated. In short, "I feel . . . that I am entitled to pecuniary recompense from the country which is benefitting [sic]... from my professional labours.",37

Except that he did not mention Jenner's successful petitions to Parliament, Ross's letter is an epitome of the themes he would use in his eventual petition. Ross wrote this letter only two years after he left India, and whatever pain prompted him to write it may have been assuaged in part by receipt of the Nobel Prize $(£ 7,800)$ in 1902 . When Ross again raised the matter of a petition in September 1913 (why he delayed so long is not clear), his lawyers referred him to Sherwood \& Co., Parliamentary Agents. ${ }^{38}$ Ross asked for advice about his petition, and he provided the Agents with accounts of his malaria researches and of Jenner's work, petitions and rewards. ${ }^{39}$

Ross and Sherwood \& Co. exchanged some thirty letters, mainly during September-December 1913. Ross drafted and redrafted his petition, asked for comment, accepted amendments, and was admonished to make his petition concise. ${ }^{40}$ In early November 1913, Sherwood \& Co. approved Ross's drafts and submitted the petition, ${ }^{41}$ with a covering letter from Ross, to David Lloyd George, Chancellor of the

\footnotetext{
35 Ross revised his journal's subtitle to embrace "scientific thought, work and affairs", the last word explaining the breadth of commentary in the publication, including Ross's frequent pieces on everything from science to spelling. George Bernard Shaw read the journal, "which I take in piously because Sir Ronald Ross is [an] entertaining heretic" (The Nation and the Athenaeum, 23 March 1923, p. 819).

${ }^{36}$ Mrs Virginia Murray, of John Murray publishers, London, kindly provided the information about Ross's income from Science Progress.

${ }^{37}$ Ross to Sir Alfred Jones, ["written sometime near the end of 1901", according to Ross's signed annotation], RA 12/061.

${ }^{38}$ Parliamentary Agents are solicitors who advise upon and route private bills, such as Ross's petition, that are meant to reach Parliament; the Agents are not lobbyists in the usual American sense. Ross's main contact at Sherwood \& Co. was a Mr H. L. Cameron.

39 Jenner's two petitions to Parliament brought him awards in 1802 and 1807 totalling $£ 30,000$ (about $£ 350,000$, or $\$ 500,000$, in 1987 money). The details are given in: J. Baron, Life of Edward Jenner, MD., London, Henry Colburn, 1838.

${ }^{40}$ H. L. Cameron to Ross, 17 October 1913, RA 37/050.

41 Some two years after this submission, Ross brought together his petition, relevant correspondence, and other related papers into a nineteen-page pamphlet entitled Correspondence concerning a petition presented to the Honorable the House of Commons, London, [privately printed], 1915, RA 37/312. The original documents comprising the pamphlet are in the Ross Archives.
} 
Exchequer. ${ }^{42}$ The body of Ross's petition is a detailed account of his malaria-mosquito research in India and of his later efforts to apply the new knowledge to control malaria in Sierra Leone and elsewhere. Lloyd George presently replied through his Private Secretary that regardless of the precedents Ross cited, "it is not in accordance with modern usage for a Petition of this character to be recommended to the House of Commons", and with that he refused Ross's plea. ${ }^{43}$

Within a few days Ross composed and sent to Lloyd George a spirited rejoinder, arguing that certain discoveries repay their discoverers, but not those that lead to general prevention of disease (his own work included) and conveyed economic and humanitarian advantages to the empire. Ross claimed that he had expended personal funds on his research, but in an egregious argument asserted that the "increased public health due to my researches actually tends to diminish my own medical practice and that of other medical men engaged upon the treatment of tropical diseases." He felt there was an exact parallel between Jenner's case and his own, that nothing since Jenner's time had abrogated his right to follow the course of petition, and he hoped that the Chancellor would allow the petition to be heard by the House of Commons. ${ }^{44}$ To this Lloyd George's Private Secretary answered that the Chancellor of the Exchequer "regrets that he is unable to depart from the decision" conveyed previously. 45

In January 1914, Ross and his Parliamentary Agents agreed that he should seek support for the petition among Members of Parliament and prominent medical men. Accordingly Ross corresponded about his petition with several MPs, including Austen Chamberlain, ${ }^{46}$ Privy Councillor and former Chancellor of the Exchequer, and J. Ramsay MacDonald, Leader of the Labour Party; also with Sir Thomas Barlow, President of the Royal College of Physicians, Sir Rickman Godlee, President of the Royal College of Surgeons, Sir Francis Champneys, President of the Royal Society of Medicine, Sir William Osler, Regius Professor of Medicine at Oxford University, and William C. Gorgas, Surgeon General, US Army.

Ross's correspondence with Chamberlain is illuminating. In a long letter to Chamberlain, Ross detailed the background of his petition. ${ }^{47}$ Chamberlain replied that for political reasons he did not feel it possible to approach Lloyd George, but he agreed with Ross "that neither the British Govt. nor the Govt. of India have done all they ought to do in this matter." ${ }^{48}$ In another letter, Chamberlain avoided a definite opinion about Ross's position but cautioned that "I feel a great deal of doubt on the subject. $"{ }^{49}$ Ross soon sent Chamberlain a copy of the petition, explaining that he was rallying the support of MPs, several of whom, including Ramsay MacDonald, had

\footnotetext{
42 Under a rule (Standing Order 60) of the House of Commons, a petition involving money must first go to the Chancellor of the Exchequer, who can decline the request, or, if he approves, pass it on to the House for a vote.

${ }^{43}$ H. P. Hamilton to Ross, 15 December 1913, RA 37/061.

44 Ross to Private Secretary [to Lloyd George], 24 December 1913, RA 37/064.

45 J. T. Davies to Ross, [undated] January 1914, RA 37/067.

${ }^{46}$ Austen Chamberlain and Neville Chamberlain were half-brothers and the sons of Joseph Chamberlain.

47 Ross to Austen Chamberlain, 8 January 1914, RA 37/157.

48 Austen Chamberlain to Ross, 10 January 1914, RA 37/158.

49 Austen Chamberlain to Ross, 12 January 1914, RA 37/160.
} 


\section{Eli Chernin}

agreed to assist: "Of course", wrote Ross, "I am urging this matter by no means for myself alone, but for the whole of science .. . [although] . . I do not pretend that I am a disinterested person" [italics added]. ${ }^{50}$ Chamberlain responded with "grave doubts as to ... [the petition] that you have put forward, though I hold that there is room for greater encouragement by the State of workers in the field of medical research. It may be that I am prejudiced by my [former] Treasury associations, but I am certainly afraid of creating what is for all practical purposes a new precedent. I am, however, glad to see the matter ventilated and discussed." 51 This brought from Ross a strong rejoinder: "My hypothesis that scientific and other services to the nation should be paid for in cash depends upon two arguments. (1) That such payment will encourage such services . . . and (2) that it is not honourable for a nation to make no effort to pay professional men whose work it has utilized, especially if it has profited by so utilizing them. Of course, the acceptance of my petition would set a second precedent in addition to that already set by Jenner; but that is precisely the point at which I am aiming ... I understand also that the Treasury will not like the idea, just as the cured patient does not always like to pay his doctor's bill!"52

In early 1914, Ross sought support for his petition from the Presidents of the two Royal Colleges and the Royal Society of Medicine, ${ }^{53}$ but the three groups took no action. In mid-February, however, Ross informed the three Presidents ${ }^{54}$ that his Parliamentary Agents now advised another change of strategy: Ross was not to solicit the Royal Colleges or the Royal Society of Medicine until he had generated support among MPs. Ross wrote to Ramsay MacDonald of the new strategy, saying it would be better if friends in Parliament would broach the matter to Lloyd George. In a rare bit of levity, Ross told MacDonald that "I consider myself a labouring man, and therefore think that you are the head of my party!"55

Ross also asked Osler's support for the petition, a copy of which he sent. ${ }^{56}$ Osler's reply, addressed to "Dear R.R.", was brief, blunt, and unique among the responses Ross received to his solicitations of support: "I have just read your petition. What an innocent lamb you are! Imagine the Welsh grin on the Chancellor when he read it! They will never do anything, and if I were in your place I would drop the whole business." 57 Ross replied in typical fashion: "No, the lawyers advise me differently . . I I therefore stick where I was, whatever the odds.",58

Soon after, Ross wrote to Gorgas, then in London, to say he was "undertaking a bold move for science" by petitioning Parliament. "It would be of great help if you would care to give me a letter saying that my researches on malaria have been of some advantage in the sanitation of the Canal Zone. I do not know whether you would

${ }^{50}$ Ross to Austen Chamberlain, 27 February 1914, RA 37/162.

51 Austen Chamberlain to Ross, 3 March 1914, RA 37/217.

52 Ross to Austen Chamberlain, 5 March 1914, RA 37/218.

${ }^{53}$ Ross to Sir Rickman Godlee, 17 January 1914, RA 37/165.

54 Ross to Sir Rickman Godlee, 2 February 1914, RA 37/172; Ross to Sir Thomas Barlow, 2 February 1914, RA 37/176; Ross to Sir Francis Champneys, 2 February 1914, RA 37/205.

${ }_{55}^{55}$ Ross to Ramsey MacDonald, 12 February 1914, RA 37/181.

${ }^{56}$ Ross to Sir William Osler, 10 February 1914, RA 37/202.

${ }_{58}^{57}$ Sir William Osler to Ross, [undated; probably 10 or 11 February 1914], RA 37/203.

${ }^{58}$ Ross to Sir William Osler, 11 February 1914, RA 37/204. 


\section{Eli Chernin}

consider yourself free to say so. The letter would not be for publication but would be sent to the Chancellor of the Exchequer..."59 To this overt solicitation of a testimonial, Gorgas responded with a classic letter of praise ${ }^{60}$ which Ross sent to Lloyd George as "important testimony" in support of his petition. ${ }^{61}$ Ross soon received word, however, that the Chancellor "fears he can add nothing to the previous letters addressed to you ...."62

His Parliamentary Agents now advised Ross to stop writing to Lloyd George and to stop encouraging others to submit petitions while his was pending, and reiterated that Ross might better influence the Chancellor by gathering recruits among MPs. ${ }^{63}$ Ross's manoeuverings in this line came to naught, except that in July 1914, William H. Cowan, MP, directed a question about Ross's petition to Lloyd George in the House of Commons, to which the Chancellor merely reaffirmed his stated opinion that the petition did not accord with "modern usage". In reply to another question about a fund to compensate scientists who did worthy but unremunerated work, the Prime Minister (Asquith) said that in his view no further provisions were needed beyond those existing, ${ }^{64}$ a position obviously at odds with Ross's.

As noted earlier, Ross made public his petition to Parliament in April 1914 in a letter to the British Medical Journal headed 'The Reward of Research', and significantly subtitled in italics, 'How to apply for it' ${ }^{65}$ The letter set out Ross's now-familiar themes, and it urged the medical profession to support reform. The news of Ross's petition generated a wave of articles, letters, and editorials in newspapers and journals, most of them endorsing his position. The most vociferous opposition to Ross came from the British Union for the Abolition of Vivisection, whose physician-president asserted that with the Nobel Prize Ross needed no more money, and that support of research encouraged the "dishonourable pursuit of vivisection" rather than the "honourable career of medicine". ${ }^{66}$ The Abolitionist also caricatured Ross in a cartoon on its cover (Plate 1). ${ }^{67}$

On 24 July 1914, ten days before Britain declared war, the Representative (policy-making) Body of the British Medical Association (BMA) "unanimously and with applause" passed a resolution endorsing Ross's petition. Dr Alfred Cox, the BMA's Medical Secretary, with whom Ross had worked closely on the resolution, sent Ross the news, which had already been forwarded to the Chancellor of the Exchequer. ${ }^{68}$

${ }^{59}$ Ross to General [William C.] Gorgas, 21 March 1914, RA 37/097.

${ }^{60}$ W.C. Gorgas to Ross, 23 March 1914, RA 37/098. Although Ross had said that Gorgas' letter would not be published, it appeared in 1915 in Ross's pamphlet (op.cit., note 41 above, p. 14), and Ross sent copies to his supporters. The letter has been republished many times since Gorgas' death in 1920; see, for example, L. J. Bruce-Chwatt, 'Ronald Ross, William Gorgas, and malaria eradication', Am. J. Trop. Med. Hyg., 1977, 26: 1077-1078.

${ }_{61}$ Ross to Chancellor of the Exchequer [Lloyd George], 15 April 1914, RA 37/103.

${ }^{62}$ H. P. Hamilton to Ross, 17 April 1914, RA 37/108.

${ }^{63}$ H. L. Cameron to Ross, 21 April 1914, RA 37/112.

${ }^{64}$ For the exchanges in Parliament see Ross, op. cit., note 41 above, pp. 15-16.

${ }^{65}$ Ross, op. cit., note 32 above, p. 941.

${ }^{66} \mathrm{~W}$ W. R. Hadwen, 'Sir Ronald Ross and his petition', Abolitionist, 1914, 6: 126.

${ }^{67}$ The doggerel at the foot of the cartoon is a parody of the poem Ross penned in 1897 to celebrate his discovery of malaria parasites in mosquitoes. Ross's original verses appear in his Memoirs, op, cit., note 1 above, p. 226, and in many other publications.

${ }^{68}$ Alfred Cox to Ross, 29 July 1914, RA 37/288. 


\section{Eli Chernin}

Ross acknowledged the BMA's support and expressed the hope that the war, just begun, would not delay further action. ${ }^{69}$ Within the month, Ross - whose elder son had by then been killed in Flanders - asked Cox if the time had not come for the BMA to urge action on the petition, ${ }^{70}$ Cox replying that because of the war he could not press the Chancellor for a reply. ${ }^{71}$ Ross, at his most obtuse, disagreed with Cox about delaying the petition because of the war: "Personally I do not see why the Chancellor of the Exchequer should be expected to abandon all business except war business especially as the war may last for years."72 Early in 1915, the BMA's Council decided that it was an inopportune time to urge government action on the petition, ${ }^{73}$ and there the matter rested for the duration.

With the war's end, Ross began to rekindle public and professional interest in awards for medical discoveries, undertaking three related activities in 1919: he tried to bring his case before the Royal Commission on Awards to Inventors; he moved to resubmit his 1913 petition (now called his "second petition") to Parliament; and he helped to organize the "Joint Committee on Awards for Medical Discoveries", representing the BMA and the British Science Guild (BSG).

\section{THE ROYAL COMMISSION ON AWARDS TO INVENTORS}

In October 1919, Ross inquired of the Royal Commission whether it could consider "inventions designed to prevent diseases", 74 and whether the nature of his discoveries in malaria permitted him to apply to the Commission. ${ }^{75}$ The Commission's Secretary replied that a medical practitioner is bound by etiquette (i.e., ethics) to communicate medical discoveries freely to the profession, the public, and to the Crown, and the same would apply to discoveries in sanitary science. ${ }^{76}$ Ross turned to the BMA's Alfred Cox to inquire about the medical etiquette and to request legal help to argue his case; Ross sought a hearing with the Commission because medical etiquette presumably required publication of discoveries and barred patents, thus penalizing the medical man "for his generosity to the world". ${ }^{77}$ Cox and the BMA Council, however, concluded that since medical ethics forbade patenting medical discoveries, the BMA could not support him before the Commission. ${ }^{78}$ When Dawson Williams of the $B M J$ also wrote that "patenting of a remedy is contrary to the traditions and practice of the medical profession", 79 Ross yielded and withdrew his application. ${ }^{80}$ Ross allowed in his letter, however, that "what exactly the medical etiquette is I really cannot make out", an imperceptive remark he all but repeated to Cox. ${ }^{81}$

\footnotetext{
${ }^{69}$ Ross to Alfred Cox, 4 August 1914, RA 37/296.

${ }^{70}$ Ross to Alfred Cox, 9 September 1914, RA 37/298.

71 Alfred Cox to Ross, 7 January 1915, RA 37/303.

72 Ross to Alfred Cox, 12 January 1915, RA 37/304.

${ }^{73}$ Alfred Cox to Ross, 5 February 1915, RA 37/308.

74 Ross to R. Tindal Robertson, 13 October 1919, RA 38/044.

75 Ross to R. Tindal Robertson, 25 November 1919, RA 38/047.

${ }^{76} \mathrm{R}$. Tindal Robertson to Ross, 9 December 1919, RA 38/049.

77 Ross to Alfred Cox, 12 Decernber 1919, RA 38/055.

78 Alfred Cox to Ross, 23 December 1919, RA 38/068.

79 Dawson Williams to Ross, 23 December 1919, RA 38/069.

${ }^{80}$ Ross to R. Tindal Robertson, 29 December 1919, RA 38/074.

${ }^{81}$ Ross to Alfred Cox, 29 December 1919, RA 38/072.
} 
THE SECOND PETITION TO PARLIAMENT

While still corresponding with the Royal Commission, Ross wrote to Cox that he meant to resubmit his petition, and that several MPs including all the medical members favoured the move. He asked Cox to write to the Chancellor of the Exchequer (now Austen Chamberlain) to remind him of the BMA's unanimous resolution of 1914 favouring the petition, and to inquire if he would now pass the petition to the House of Commons. Ross's letter to Cox closes: "Please note that I am asking Parliament not for reward for my investigation, but for compensation for loss of professional involvement owing to my work on malaria. That was also the ground on which Edward Jenner appealed. The appeal for compensation is of course always stronger than the one for reward." 82 Cox promptly obliged, but five months later, in April 1920, Ross himself asked Chamberlain to pass the petition to the House, naming eight MPs who favoured his petition and citing support from the BMA and the BSG. ${ }^{83}$ Chamberlain replied through his Private Secretary that he saw "no sufficient reason to depart from the decision arrived at ... by his predecessor in 1913", and further, that it was not "in accordance with modern usage" to recommend a petition of this character to the House. ${ }^{84}$ Chamberlain's response was, of course, foreshadowed by the "grave doubts" he had expressed to Ross about the first petition five years earlier. ${ }^{85}$

On behalf of Ross and the BMA, Cox wrote a strongly worded letter to Chamberlain: "The [British Medical] Association is unable to understand why the precedent of petition is no longer open. Surely it is the right of every one of His Majesty's subjects to ask the House of Commons for similar relief."86 Chamberlain, however, refused to alter his decision, ${ }^{87}$ an inquiry aimed at passing the petition directly to the Speaker of the House proved futile under the rules, ${ }^{88}$ and thus Ross's petition failed again. Ross, however, remained undeterred.

THE JOINT COMMITTEE OF THE BMA AND THE BSG

The BSG, founded in 1905 by the long-time editor of Nature, Sir Norman Lockyer, was a pressure group dedicated to promoting and organizing scientific work. In 1916, the BSG appointed Ross chairman of a committee which recommended that the government's practice of using consultants without payment of fees was unjust and should be abandoned; in consequence, Ross himself regretfully resigned several Colonial Office committees. ${ }^{89}$ A year later, the BSG and the BMA formed a "Joint [sometimes called Conjoint] Committee on Awards for Scientific Discovery", charged to explore the inadequacies of government recompense for the achievements of medical scientists. Ross felt that "The Committee managing the affair should consist only of men with straight minds and the highfalutin' medical philosopher should be excluded." 90 In the

82 Ross to Alfred Cox, 20 November 1919, RA 38/136.

${ }^{83}$ Ross to the Chancellor of the Exchequer [Austen Chamberlain], 29 April 1920, RA 37/397.

${ }^{84}$ A. F. Hemming to Ross, 6 May 1920, RA 37/399.

${ }^{85}$ Chamberlain, op. cit., note 51 above.

${ }^{86}$ Alfred Cox to Austen Chamberlain, 14 May 1920, RA 37/408.

${ }^{87}$ A. F. Hemming to Alfred Cox, 18 May 1920, RA 37/409.

${ }^{88}$ E. Cadogen to Alfred Cox, 18 June 1920, RA 38/220.

${ }^{89}$ Ross, op. cit., note 1 above, p. 517.

90 Ross to E. B. Turner, 28 May 1919, RA 38/083. 
event, a formidable Joint Committee was constituted: Sir Clifford Allbutt, Prof. Benjamin Moore, Prof. J. S. Haldane, Mr E. B. Turner, and Dr R. T. Leiper (for the BMA); and Lt. Gen. Sir Alfred Keogh, Sir Ronald Ross, Prof. W. M. Bayliss, Sir Richard Gregory, Lt. Col. W. A. J. O'Meara, and Dr D. Somerville (for the BSG). ${ }^{91}$

Ross prepared a draft report on rewards for medical discovery, which the Joint Committee adopted with modifications and forwarded to the Medical Committee of the House of Commons and to the lay and professional press. ${ }^{92}$ The report emphasized: (i) that the precedent of Jenner petitioning Parliament should be revived; and (ii) that Parliament should provide an annual sum of $£ 20,000$ to be disbursed as life-pensions, of $£ 500$ or $£ 1,000$ each, to men judged to have made worthy medical discoveries. The report distinguished (in italics) between compensation meant as an "act of justice" to reimburse the researcher's losses, and reward meant as an "act of grace" for sevices rendered. Underlying the document lay the principle that medical discoveries should not be allowed to inflict unrecompensed financial loss upon the investigators.

Near the end of February 1920, Ross learned that A. J. Balfour, formerly Prime Minister and now Lord President of the Council, had agreed - as Minister responsible for scientific research - to receive a Deputation to discuss the Joint Committee's report ${ }^{93}$ Several medical MPs and the members of the Joint Committee comprised the Deputation for the 2 March meeting. When the Deputation met with Balfour, distinguished members of the group stressed the need for awards for medical scientists on moderate salaries, whose achievements could not be disposed of to the public for profit. Balfour replied that some remedy should be found, and thought that when he reported the discussion the Prime Minister (now Lloyd George) would give it sympathetic consideration. Balfour did not specifically exclude the precedent of Jenner for rewarding exceptional service, but he thought that petitions to Parliament were not the way to deal with discovery. When Balfour also expressed concern about the difficulty of selecting the men responsible for a discovery, Ross responded that the methods used by the Royal Society in selecting its Fellows, and those used by the Nobel Committee for awarding its prizes, could be adapted. ${ }^{94}$

The representations to Balfour were reported in professional journals and in the British press, whose editorials favoured the Committee's position. Balfour, however, maintained further silence until the BMA-BSG inquired formally, several months later, whether a decision had been reached. ${ }^{95}$ Balfour replied through his Private Secretary that he had nothing to add to his remarks to the Deputation, and that he had pointed out difficulties making it impossible to adopt the policy advocated by the Deputation. ${ }^{96}$ In a signed handwritten note, written in 1923 and bound atop his archival file on the Deputation, Ross said of Balfour: "He gave us the usual

91 [Report of Joint Committee], 'The needs for rewards for medical discovery', Lancet, 1920, i: 112-113.

92 Minutes of the Joint Committee on Awards for Medical Discovery, 19 December 1919, RA 38/265.

93 Nathan Raw to Ross, 24 February 1920, RA 38/251.

94 [Report on the Deputation to the LPC], 'State grants for scientific investigation. Deputation to the Lord President', Br. med. J., 1920, i: 346-347.

95 A. D. L. Lacey and A. Cox to A. J. Balfour, 23 June 1920, RA 38/267.

96 E. Lascelles [to A. D. L. Lacey and A. Cox], 24 June 1920, RA 38/274. 


\section{A BOLITIONIST. \\ THE JOURNAL OF \\ The British Union for the Abolition of Vivisection. (THE BRITISH ANTI-VIVISECTION SOCIETY.)}

No. (i. Vol. XV.]

JNE 1, 1914.

Pricr 2d.

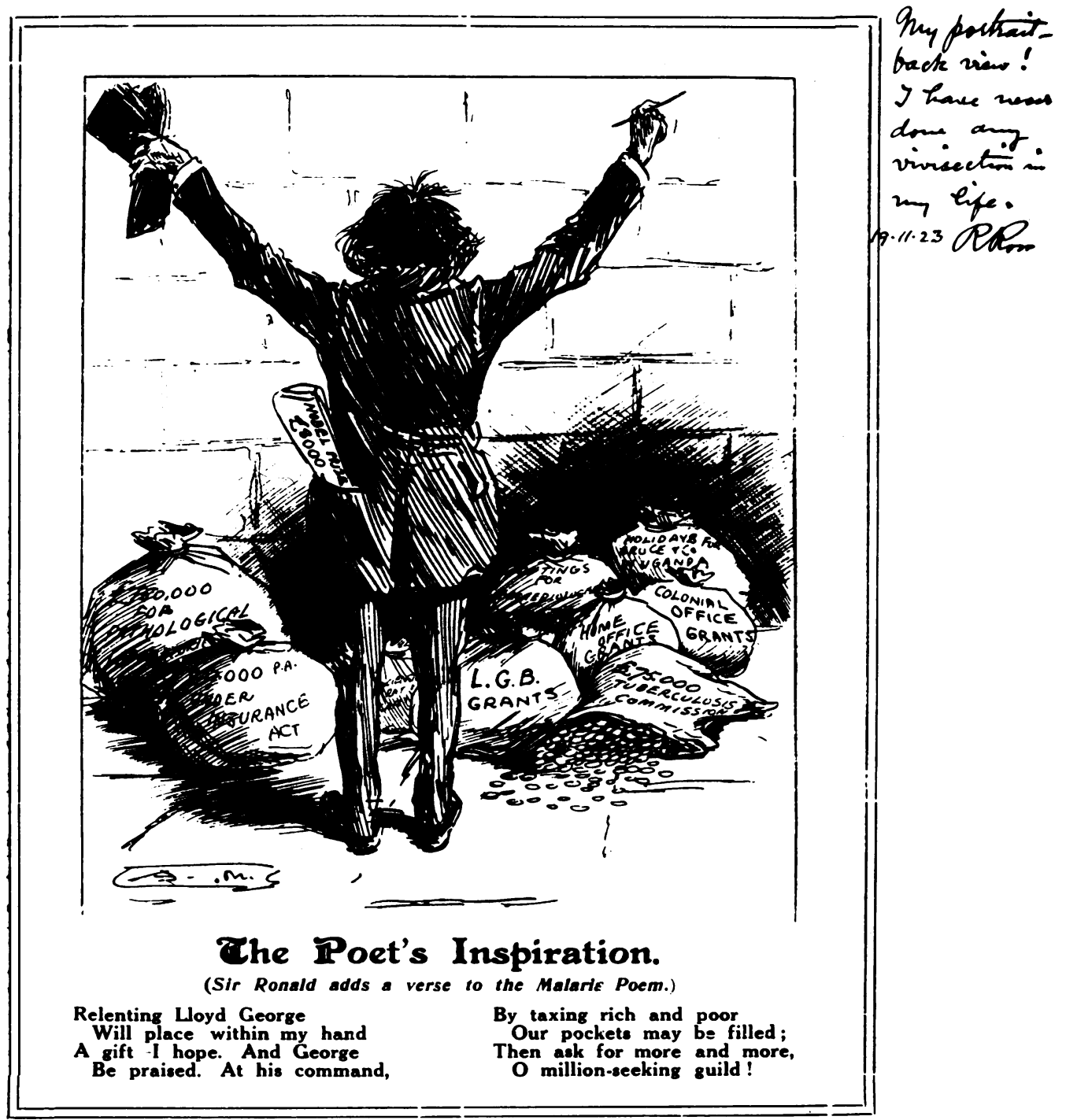

Plate 1 Cartoon on the cover of the Abolitionist ridiculing Ross and his fundraising for medical research, Ross's Nobel Prize sticks out of his pocket, and bulging moneybags lie about, including one labelled "Outings for bacteriologists". Ross's signed marginal annotation of 1923 reads: "My portrait —back view! I have never done any vivisection in my life." See also note 67 above. Figure from the Ross Archives, reproduced by the Department of Visual Aids, and published by courtesy of Professor David J. Bradley, Ross Institute of Tropical Hygiene, London School of Hygiene and Tropical Medicine. 
maundering indecisive reply, and had evidently never bothered to read our Report."97

In July 1920, the Presidents of the BSG and the BMA wrote jointly to Lloyd George documenting their groups' efforts on behalf of awards for medical discoveries, and asking how those who made valuable medical or sanitary discoveries could appeal for compensation for pecuniary losses incurred by their work. Their letter concluded that it "seems to be a hardship that such rewards as [Jenner's] are now withheld from medical men though they are allowed for soldiers and sailors, and, in the form of patents, for inventors... The chief thing required is a scheme which will provide adequate recompense for results of national value achieved by medical, sanitary, or other scientific workers."98 There is no record that Lloyd George replied to this letter; indeed, a year later, Ross wrote to The Times that the Prime Minister still had the matter under consideration. ${ }^{99}$ Ross argued in his letter that "It is precisely because medical men do not patent their ideas that the State should endeavour to reward them in other ways." This prompted Frank Briant, MP, to ask Balfour, in Parliament, whether a fund could be provided from which awards could be paid for discoveries or inventions placed gratuitously in public service. Balfour replied that he doubted that any system of pecuniary awards would benefit science or medicine, and that the difficulty of apportioning merit was "overwhelming". Ross published this exchange verbatim, and he challenged Balfour about the difficulty of apportioning merit. If so, asked Ross, how could any rewards ever be given: university honours, fellowships in learned societies, state honours (including the Victoria Cross), or the Nobel Prizes? ${ }^{100}$

Some who argued over the relative worth of inventions pointed to the often ludicrous inconsistencies of a thoughtless society. One columnist remarked that "The inventor of a new hairpin would probably make a fortune, while the genius who discovered a cure for cancer or consumption would get no pecuniary recompense at all." 101 Another writer claimed that his own humanitarian invention was rejected by the Royal Comission on Awards to Inventors, which, however, "gave a considerable reward to the inventor of an improvement in nosebags for horses!"102 Ross, reflecting on his own encounter with the Royal Commission said "it refused to consider medical discovery and invention because (it argued) doctors had always been noble enough to do such public work for nothing! We may be sure that the lawyers on the said Commission do not follow their example."103

Ross published his Memoirs in 1923, but that large book provides only scant accounts of the petitions and similiar involvements that had so exercised him. He kept these issues alive, however, in speeches, in newspaper pieces by and about him, and in many articles in Science Progress. In a speech to a 1923 meeting of the BSG, for example, Ross declared that the world throws its scientific geniuses on the "dustheap", named several neglected scientists (the examples seem ill-chosen), and urged Britain to pension such men liberally and thus encourage them to further investigations. He also

97 R. Ross, [untitled note], 25 November 1923, RA 38/288-340.

98 Montague of Beaulieu and C. Allbutt to the Prime Minister [Lloyd George], 14 July 1920, RA 38/273.

$99 \mathrm{R}$. Ross to Editor of The Times, 13 July 1921, p. 8.

100 R. Ross, 'How to encourage science', Sci. Prog., 1921, 16: 286-288.

101 A. G. Church, 'Masters of science and their masters', Humanist, 1 April 1920, p. 50.

$102 \mathrm{~W}$. Hampson, quoted by Ross, op. cit., note 100 above, p. 288.

103 Ross, op. cit., note 1 above, p. 517. 


\title{
Eli Chernin
}

urged a scheme of rewards offering five prizes of $£ 1,000$ and ten of $£ 500$ a year, a variant of the earlier Joint Committee's recommendations. ${ }^{104}$

Accounts of Ross's speech appeared in many newspapers, usually with eye-catching headlines and sympathetic editorials. The Daily Graphic wrote, for example, that "England owes more to her scientific men than any other country, and she rewards them least. Time and again it happens that when a genius proves himself a national benefactor his sole reward is a knighthood ... but you cannot live on it by itself. Research workers mostly live on bread and butter, and too often their most valuable discoveries do not so much as provide jam." ${ }^{105}$ A pseudonymous commentator in the Outlook declared that "Sir Ronald Ross has, I suppose, saved more lives than any man living, and on a per capita grant of a penny each life he would be a wealthy man. But I believe his reward will come in the shape of praise, not pudding."106

Other periodicals were unsympathetic. One magazine, for example, reported that the meeting of the BSG at which Ross spoke "tailed off into a demand for pensions for scientists . . . Here was a meeting of the ablest and wisest men in London, and all they could do was to call for doles, as though they were a crowd of unemployed in Hyde Park."107 The New York Times also weighed in with critical comment:

\begin{abstract}
What Sir Roland [sic] forgot ... is that men of the sort he had in mind do not work for pay or even for fame; in theory, and often in practice, their object is to increase the general stock of knowledge, and they expose themselves to deserved condemnation by their fellows if they attempt to capitalize their discoveries in the way of the ordinary business man. They are expected to make public whatever they find, and are disgraced if they patent their inventions or keep secret their processes. That being the case, why is it a grievance if, lacking commercial abilities and intentions, they do not acquire the fortunes of men who have those abilities and intentions? As a matter of fact, very few, if any, savants ever starved or went to the poorhouse .... 108
\end{abstract}

Had Ross chosen to reply to these arguments, he might well have used a line he coined years earlier: "The world does not value what it does not pay for."109

\section{THE ROSS INSTITUTE CREATED}

Coincident with these public debates on the rewards of science, and with the approaching twenty-fifth anniversary of Ross's mosquito-malaria work in India, a letter to The Times announced a scheme to establish a research institute named in Ross's honour. The letter appealed for $£ 50,000$ in subscriptions and was signed by thirty-three dignitaries including the former Prime Minister, Asquith. (Despite the impressive signatories, poor finances plagued the Ross Institute and Hospital for Tropical Diseases from its opening in 1926 until Ross's death.) The Institute's objectives were seen as laboratory and clinical research, and, as the letter declared, "Ross - a master mind - assisted by other experts . . . [was to] have the fullest scope for . . . researches into the still unsolved problems of tropical medicine and hygiene."110

104 Evening Standard, 28 February 1923, p. 7.

105 Daily Graphic, 1 March 1923, p. 7.

106 "Nemo" in the Outlook, 10 March 1923, p. 187.

107 Efficiency Magazine, April 1923, p. 34.

108 Topics of the Times: 'They do not ask for payment', New York Times, 2 March 1923, p. 14.

109 Ross to G. A. Buckminster, 5 May 1914, RA 37/244.

${ }^{110}$ H. H. Asquith, et al., to the Editor of The Times, 22 June 1923, p. 15. 


\section{Sir Ronald Ross, malaria, and the rewards of research}

The senior research Directors of the Institute were Sir William Simpson and Sir Aldo Castellani, joined later by Sir Malcolm Watson. Sir Ronald was, of course, the nominal Director-in-Chief, but it appears that his physical and perhaps his mental health had begun to fail even before the Institute opened. Ross himself recorded the onset of intermittent claudication in 1917, ${ }^{111}$ and by 1925 he had developed diabetes (of which his father had died), ${ }^{112}$ arteriosclerosis, and migraine; ${ }^{113}$ he was also a heavy smoker. ${ }^{114}$ In 1927 , Ross suffered a stroke which paralysed his left side, and in 1928, he told a reporter "I am blind in my left eye". ${ }^{115}$ Ross died in September 1932, whereupon the Institute's governors moved to amalgamate it with the London School. ${ }^{116}$ By the Spring of 1934, the Ross Institute had been incorporated into the London School as a department called "The Ross Institute of Tropical Hygiene". Its distinguished Directors have been the late Sir Malcolm Watson and the late Professor George Macdonald, and Professor Emeritus Leonard J. Bruce-Chwatt, and the present incumbent, Professor David J. Bradley.

The advent of the Ross Institute and his illnesses did not deter Ross from continuing to claim money for his mosquito-malaria research. Indeed, Ross fuelled the fires of that issue in 1928 when he offered to sell his personal papers.

\section{THE ROSS ARCHIVES FOR SALE}

It hardly exaggerates to say that Ross created a sensation in the British press when he inserted a half-page notice into the October 1928 issue of Science Progress announcing that his personal archives were for sale, including his manuscripts, correspondence, expedition reports, and mathematical works. ${ }^{117}$ The reaction to Ross's announcement is evident in such newspaper headlines as these: "Historic malaria documents/Why Sir Ronald Ross is selling out/Attack on politicians;"118 "Owes Britain a grudge/Famous scientist in need/To sell MS;" 119 "Sir Ronald Ross's disclosure/Not a penny in recognition of great discovery/Politicians who can only chatter;" 120 "Forgotten by his country/Sir Ronald Ross/Rewarded only by my King/Life work for humanity;",121 and, under Ross's own by-line, "What science has done to me". ${ }^{122}$

In an interview typical of most, Ross declared "I am not selling my archives because I have to but simply because I should like to realize money on them for the benefit of my children [both well married]. I do not mind who buys them. I would sell to America, but should prefer that the purchaser should be a Britisher... My price is not less than

111 Ross's pocket diary, 31 August 1917, RA 69/180.

112 Ross, op. cit., note 1 above, p. 15.

113 B. E. Beaumont, 'Sir Ronald Ross; a bio-bibliography', unpublished MA Thesis, Belfast, Queen's University, 1974, p.559.

114 Ross, op. cit., note 1 above, p. 30.

115 Glasgow Daily Record and Mail, 3 October 1928, p. 5.

${ }^{116}$ [Unsigned], 'The Ross Institute and the London School of Hygiene and Tropical Medicine', Br. med.J., 1933, ii: 245-246.

117 [Advertisement of sale of the Ross Archives], Sci. Prog., 1928, 23: viii.

118 Aberdeen Evening Express, 10 October 1928, p. 5.

119 Glasgow Daily Record, 10 October 1928, p. 5.

120 Birmingham Evening Dispatch, 2 October 1928, p. 1.

121 Daily Mail, 10 October 1928, p. 9.

122 Daily Express, 4 October 1928, p. 10. 


\title{
Eli Chernin
}

$£ 2,000$ but I hope to receive a higher amount."123 Elsewhere, he said of the sale, "Mind you, I am not pleading poverty. I earn my living [£500 p.a.] at the institute ... I could manage without the $£ 2,000 ",{ }^{24}$ and in almost every interview, Ross recalled that his petition to Parliament had been refused by Lloyd George and Austen Chamberlain.

Ross's archives went on sale just as his new books, Poems and Studies on malaria, were coming under press review, and the reviewers inevitably commented on Ross's sacrifice of his archives, "his most treasured possessions, the lovingly compiled records of his life-labour . . .."125 And a famous friend of Ross's, who could play both the literary and the medical sides of the fence, wrote to the press that: "The State makes a grant to a successful general. Ronald Ross has been the most successful of all generals, winning victory of the human race against the Malaria Fiend which has claimed its victims by the million. Is it not a scandal that the human race should do so little in return? . . . ." [signed] Arthur Conan Doyle. ${ }^{126}$

In November 1928, Ross sold his documents for $£ 2,000$ to Lady Houston, DBE, the wealthy widow of a shipping magnate. The larger part of the Ross Archives, some 20,000 items, is now preserved in the Library of the London School of Hygiene and Tropical Medicine; the remainder, about 12,000 documents, is kept as the Ross Collection in the Library of the Royal College of Physicians and Surgeons of Glasgow. ${ }^{127}$

Ross's sale of his papers engendered much commentary. According to one newspaper column, typical of many, the Rt. Rev. Frank Woods, Bishop of Winchester, declared from the pulpit at York:

The Dago cacophonist in the jazz-king film ["The Jazz Singer," 1927] receives a quarter of a million sterling income. A man like Sir Ronald Ross, whose work brought health to hundreds, if not thousands, has the prospect of a meagre Civil List pension. For Jackie Coogan [of whom see below] immortality; for the [memorial] of Thomas Hardy, a hardly extracted thousand pounds.

The article commented that the Bishop's salary of " $£ 6,500$ a year is a pretty picking, even for a Prelate", and asked:

\begin{abstract}
Who is the "Dago cacophonist in the jazz-king film?" If the Bishop means Al Jolson he should be told that $\mathrm{Al}$ is not a Dago, or a Greaser, or a Squarehead or a Guinea or a Nigger. We use the words only for illustration and without reflection on the people of the nationalities suggested by the words. We deprecate any other use of them.
\end{abstract}

The writer then disclosed that Jolson was a Jew, and contrasted the ghetto upbringing of the immigrant entertainer with the Bishop's gentler background, concluding that both "the Bishop and the Dago cacophonist have come a long way in the world", and that "Dr Woods seems to confuse money value with real value". ${ }^{128}$ (Sir Edward Parry supposed in the press that "dago cacophonist" might be "episcopalese for a negro minstrel with a saxophone", but that both minstrel and bishop got far more money than Ross.) ${ }^{129}$

123 Ross, op. cit., note 120 above.

124 Ross, op. cit., note 121 above.

125 Daily Telegraph, 23 October 1928, p. 6.

126 Arthur Conan Doyle to Editor ['The case of Sir R. Ross'], Daily Express, 6 October 1928, p. 10.

127 Gibson, op. cit., note 9 above, pp. 23-27.

128 “H.W.S.", 'Measuring men', Liverpool Daily Courier, 12 November 1928, p. 11.

129 E. Parry, 'Your value as a human being', Sunday Chronicle, 18 November 1928, p. 3. 
The Bishop had referred to Jackie Coogan ("The Kid"), the fourteen-year-old American entertainer, because Coogan was about to perform in London at $£ 1,000$ a week. Newspapers pointed out that "A fortnight's salary for a boy film actor is as much as Sir Ronald Ross got for the records of his life's work." ${ }^{130}$ Other newspapers also drew comparisons and decried the fact that rich spoils should go to company promoters, film stars, and leaders of jazz bands, while "For his great contribution to the conquest of malaria, Sir Ronald Ross has received - nothing."131

In the midst of this, Sir James Barr, a one-time President of the BMA, and something of a "tearing demagogue", ${ }^{132}$ wrote two letters to newspapers, one declaring that "Ronald Ross is at present in very bad health and in his declining years he and all those near and dear to him should be set free from all financial worries"; 133 and the second suggesting that an influential committee should be formed to raise "at least one million shillings as a just tribute to Sir Ronald Ross, and I should leave him entirely free to dispose of the money as he thought proper."134

At about this juncture, in November 1928, George C. Shattuck, MD, scion of a prominent Boston medical family, and then Assistant Professor of Tropical Medicine in the Harvard Medical School, apparently concerned about Ross's health and finances, wrote to his friend Theodore Dyke Acland, a London physician descended of famous physicians. Shattuck's letter is lost, but the nature of his inquiry is evident from Acland's replies:

[Ross] has, I think we may rightly say, been badly treated by this country in so far as he has not received any pecuniary reward for his discoveries, which have been of such value. I send you, in strict confidence, a statement of his financial position [this statement is lost], from which you will see that although his present income is sufficent for anyone with modest wants, it does not enable him to put by enough to provide for his wife and family after his death. ${ }^{135}$

One day later Acland sent more explicit information:

[I] am informed that Sir Ronald Ross has no private means, that all his permanent income is derived from the residue of the Nobel Prize, of which he was obliged to spend a considerable part (i.e., $£ 3,700$ out of a sum of $£ 8,000$ awarded to him) to meet his immediate liabilities: I think that you now have all the facts, as far as they can be ascertained ... . Sir Ronald has a grievance which is intelligible, namely, that, although his researches have been of great service to the community, the community has not given him any pecuniary reward. ${ }^{136}$

How Acland learned about Ross's personal affairs is problematical, but his letters provide the only specifics we have about Ross's financial worth in the late 1920s.

In May 1929, six months after he suggested raising a fund for Ross, Sir James Barr wrote to the British Medical Journal saying that a group had formed the "Ross Award Fund" as a testimonial to Ross for his malaria work, and the fund invited

${ }^{130}$ Manchester Dispatch, 20 November 1928, p. 8.

131 Edinburgh Evening Dispatch, 13 November 1928, p. 4.

132 A. Cox, Among the doctors, London, Christopher Johnson, 1950, p. 87.

133 J. Barr to Editor, Daily Mail, 10 October 1928, p. 12.

134 J. Barr to Editor, Morning Post, 18 October 1928, p. 5.

135 T. D. Acland to G. C. Shattuck, 21 November 1928. Uncatalogued letter in Harvard Medical Archives, Countway Library of Medicine, Boston.

${ }^{136}$ T. D. Acland to G. C. Shattuck, 22 November 1928. Provenance as in note 135 above. 


\section{Eli Chernin}

subscriptions. ${ }^{137}$ About two years later, this notice appeared in the Journal: "Sir James Barr (Chairman of Committee, Ross Award Fund) writes: I beg to inform you that the total sum raised for Sir Ronald Ross amounted to $£ 15,513.5 \mathrm{~s}$. 6d. Thanks to this fund, Sir Ronald Ross's anxiety for the late Lady Ross [d. September 1931] was removed, and his declining years are being made happier. The fund is now closed."138 As fortune would have it, Ross died on 16 September 1932, the day before this fund formally closed.

The story of the fund is not closed, however, because we do not know how or how much of the fund was disbursed during or after Ross's lifetime. In the United States, incidentally, a medical group opened the "Ross Award Fund of America", describing Ross as a "poor man". ${ }^{139}$ This appeal brought in about $\$ 500$ before Ross's death. 140 While it is unclear whether any of the Ross Fund moneys were included in Ross's holdings, he left an estate of the "gross value of $£ 7,403$, with net personalty

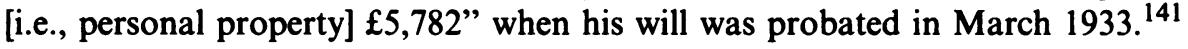

\section{"SWEATING THE SCIENTIST"}

Soon after becoming the editor of Science Progress in 1913, Ross published prominent notices headed 'The Emoluments of Scientific Workers', listing questions to which volunteer respondents were asked to reply for an inquiry into "the pay, position, tenure of appointments, and pensions of scientific workers and teachers ...."142 The replies, said Ross in an unsigned article called 'Sweating the Scientist', "suffice to prove the low scale of payment given throughout the British Empire for [scientific] work." Ross asserted that "the sweated labourer [i.e., the scientist] is the highest type of intellect in the country", 143 but that capable minds had been turned away from humanitarian fields, leaving the remainder to produce much petty science. A newspaper piece called 'Sweated Brains', by "A Scientist" (likely Ross), observed that: "A glance at the university posts advertised in . . . Nature, will throw much light on the scale of pay, but will give too favourable an impression of the stipend of the teacher-researcher. For the worst-paid posts are not advertised, but filled privately by the modern university from among the best of its own students." 144 This practice existed because some bright, well-off young men taught for nominal stipends, and by this "blacklegging" allowed the university to avoid paying decent salaries to its teachers. ${ }^{145}$ In yet another unsigned essay, Ross repeated his views on the poor emoluments of scientists, and, in a transparent allusion to his own departure from

137 J. Barr to Editor, Br. med. J., 1929, i: 879.

138 J. Barr to Editor, ibid., 1932, ii: 576.

139 F. L. Hoffman to Editor, J. Amer. med Ass., 1932, 98: 249-250.

140 R. L. Pitfield to Editor, ibid., p. 1576.

141 'Wills and bequests', The Times, 20 March 1933, p. 15.

142 [Unsigned; attributed to Ross], 'Notice. The emoluments of scientific workers', Sci. Prog., 1914, 9: 196.

143 [Unsigned; attributed to Ross], 'Sweating the scientist', ibid., 1914, 8: 599-607. According to Ross, half-time medical scientists in Britain received nothing or up to $£ 85$ annually, salaries below full professor's ranged from $£ 120$ to $£ 250$, and full-time professors earned around $£ 600$; some posts included small contributory pensions, but no insurance against illness, accident, or death. Only rare non-clinical professorships brought $£ 1,000$ a year, and retirement was sometimes mandatory at sixty or sixty-five.

144 [Unsigned; attributed to Ross], 'Sweated brains', Daily Mail, 5 June 1914, p. 6.

145 "Sudo", 'The rewards of research', New Statesman, 16 May 1914, p. 174-175. 


\section{Sir Ronald Ross, malaria, and the rewards of research}

Liverpool, he mentioned the plight of "professors [who] have been obliged to leave their universities after 15 or more years of service without any pension whatever . . ."146

The world war delayed Ross's petition to Parliament, but it did not stop him publicizing his cause. In October 1915, Ross published a caustic (unsigned) essay called 'Mr Lloyd George, the nation of shopkeepers, and the Pied Piper of Hamelin'. In the essay, Ross gives a third-person account of his petition to Parliament, and he draws a parallel between the refusal of the burghers of Hamelin to pay the Pied Piper for ridding them of rats, and Lloyd George's refusal to compensate the modern Pied Piper. In the fable, the Hameliners lose their children in punishment; in Ross's parable the country loses its capable scientists and their beneficent researches. Ross's feelings about the stupidity of government towards science are exemplified by a bitter statement that appears - twice - in his Hamelin essay: "It is more profitable to be a rogue than a genius." 147 Ross's frustration also found voice in an unsigned poem entitled 'Rewards', in which scientists, writers, and musicians are said to go unhonoured while the wrong men are rewarded. The poem ends: "Who stands upright in Britain falls./He wins the prize of life who crawls."148

Ross pursued other lines of the argument in his Memoirs, at one point invoking the shades of Walter Reed, who died untimely in 1902. Speaking on behalf of those who had won "decisive scientific victories", Ross said, "If I were a millionaire I should give my money, not to institutions, academies, and universities, but to men like Reed, in order to make them independent for life. Those who have actually won decisive scientific victories in the past know best how to win similar victories in the future."149 Elsewhere, in 1924, Ross explicitly urged creation of research professorships, an idea whose time would not come until after the Second World War. ${ }^{150}$

Although Ross acknowledged that readers were doubtless weary of his writings about encouraging medical discovery, ${ }^{151}$ he saw no choice but to reiterate in order to hold public attention. In conceding that "No reform is likely to be effected in my time", Ross nevertheless set down his key precepts on medical research: that it is a matter of honour to give medical scientists professional payment; and that there should be "payment for results in addition to the present system . . . of payment for expectations"152 [italics in original].

Ross's "payment for results" would not be his. When many friends gathered on 20 August 1930 to celebrate the thirty-third anniversary of Ross's mosquito-malaria discovery, Sir William Simpson referred in his speech to the millions of lives Ross's discovery had saved: "It was the work of a genius, but Sir Ronald is a genius who is not satisfied with that; he has also become a poet and a mathematician. But there is one

\footnotetext{
146 [Unsigned; attributed to Ross], 'Science and the state', Sci. Prog., 1914, 9: 200-201.

147 [Unsigned; attributed to Ross], 'Mr. Lloyd George, the nation of shopkeepers, and the Pied Piper of Hamelin', ibid., 1915, 10: 315-322. (The quoted sentence is on p. 321.)

148 [Unsigned; attributed to Ross], 'Rewards', ibid., 1922, 16: 632-633.

149 Ross, op. cit., note 1 above, p. 426.

150 R. Ross, 'Independent versus subsidized research', Sci. Prog. 1924, 18: 454-455.

151 R. Ross, 'The encouragement of discovery', ibid., 1926, 20: 95-97.

152 R. Ross, 'The encouragement of medical discovery - a summary', ibid., 1926, 20: 413-416.
} 


\section{Eli Chernin}

thing he cannot do - and I want to impress it on you - he cannot make money."153 Such was the judgement passed on Ross within his hearing only two years before his death.

Ross had commented in 1914 that failure to reward distinctive work in science, literature, and art, "really springs from the curious and stupid attitude of the public towards all forms of intellectual effort". ${ }^{154}$ With the war in progress, Ross informed "Brainless Britain" that "science and art are of no value to our politicians because they do not provide votes. Nothing is to be done for the intellectual side of life, everything for the non-intellectual", and, further, "that the average intellect of the mass of the British public of to-day, including that of their rulers, is very much below par." 155 This reflected, as Ross later wrote in his Memoirs, the "national indifference to all intellectual effort which our fathers called Philistinism." 156 Ross's attacks grew more contemptuous; he declared, for example, that the mass of Britishers "remain in the intellectual condition of the Wigwam age." 157 It hardly surprises that Ross dedicated his Memoirs to the people of Sweden, not Britain.

Ross was not alone in his concern about flagrant anti-intellectualism, public and private ignorance of science, and the dead-handed scholasticism of the educational establishment. Negative attitudes about science, however, pervaded much of British society where "the average jam or pickle maker will leave a legacy to a hospital or his local church, but he has no more use for science than [for] the French Revolutionaries or the Russian Bolsheviks." 158

\section{DISCUSSION}

For thirty years, Ross persevered - perseverated might be closer — in seeking from Britain monetary reward for his solving the "great malaria problem". ${ }^{159}$ Despite his many honours and awards, including the Nobel Prize, Ross's desire for a Jenner-like recognition from his government was never appeased. In his unremitting pursuit of money, Ross proved aggressive, resourceful, and contentious, and he never lacked for words. But the logic of a mathematical mind and a poet's metre won Ross no battles with authorities, some of whom he came to curse as "Cleons". 160

Ross and his family probably lived comfortably, but since the archival records are largely silent on his childhood and family affairs, the origins of Ross's penchant for pecuniary remuneration are not clear. Some of Ross's general schemes were, he said, altruistic, but he made no bones about having a personal interest in them. Whatever the antecedents, Ross and his professional contemporaries were seriously concerned with

153 R. L. Mégroz, Ronald Ross. Discoverer and creator, London, Allen \& Unwin, 1931, p. 252.

154 Ross, op. cit., note 143 above, p. 607.

155 [Unsigned; attributed to Ross], 'Brainless Britain', Sci. Prog., 1914, 10: 658-660.

156 Ross, op. cit., note 1 above, p. vi.

${ }^{157}$ R. Ross, 'The King and tropical medicine', Sci. Prog., 1924, 19: 118-119.

158 "Nemo", op. cit., note 106 above.

159 Ross, op. cit., note 1 above, from the subtitle to Memoirs.

160 Cleon was an Athenian considered an unprincipled demagogue. Ross, op. cit., note 1 above, p. 372 , characterized as a Cleon Chairman Arthur Jones of the Liverpool School, and also Lloyd George who had refused Ross's first petition (ibid., p. 516); in the ultimate insult, Ross characterized Jones as a "Lloyd George" (ibid., p. 372). 


\section{Sir Ronald Ross, malaria, and the rewards of research}

personal status, no small matter in a profession in which manners and bearing sometimes counted for more than medical ability. ${ }^{161}$ While admittedly speculative, the knighthood bestowed on Ross in 1911 may have pushed him to "live up" to the more costly standard he encountered when he moved in 1912 to London's Cavendish Square, ${ }^{162}$ the nidus from which Harley and other "medical" streets extend. Whether these were causal or coincidental considerations, Ross finally petitioned Parliament in 1913, a dozen years after he first mooted the idea. ${ }^{163}$

It should be remembered that Ross first catapulted into prominence around 1900 on the strength of an important discovery made when medical science was beginning to gain prominence and respectability. Yet Ross's relatively modest origins, his lack of a university degree, his remote medical career in the IMS, and his want of a private income, doubtless contributed to his chip-on-the-shoulder attitude. Ross travelled in the high company of medicine but he was not naturally of it. He came on the scene as an assertive achiever and evolved into an accomplished publicist-polemicist with a platform in Science Progress and with easy access to major journals and newspapers. Neither government nor the profession could safely ignore him, and both seemed uncomfortable coping with him. Transmogrified by the distinction of the Nobel Prize into an exemplar of the new breed of medical scientist, Ross was as much caught up in change as were those who resisted it. Ambivalence must have afflicted Ross, a nineteenth-century man cast in twentieth-century roles. Even regarding the petitions Ross's attitudes betrayed uncertainties. For example, Ross said (in 1923) that he had "formed the rash scheme of following the precedent of Edward Jenner", but did so "I confess with some satiric laughter and full expectation of failure", 164 a thought he had also expressed earlier. ${ }^{165}$ Ross's "confessions" do not ring true.

Ross might never have petitioned Parliament but for the Jennerian precedents. The question then arises: if Jenner's introduction of smallpox vaccination was a work worthy of parliamentary reward, was the mosquito-malaria discovery of similar stature and worthy of similar reward? Had Lloyd George or Chamberlain said "no" to that question, Ross might have found the reply more palatable than his being fobbed off with "not in accordance with modern usage", an example of bureaucratic non-speak worthy of an Orwell.

Smallpox was unquestionably the most devastating epidemic disease of all time. By 1800 , vaccination had reached America, and missions were spreading vaccination around the world. ${ }^{166}$ Britain had a hero in Jenner, it could afford to spread the largesse of vaccination internationally, and it enjoyed a growing pride in its imperial and industrial status; all these, and the indisputable fact that smallpox was a serious plague in the home islands, worked to favour Jenner's petitions. Parliament may have

\footnotetext{
161 Peterson, op. cit., note 5 above, p. 39. Furthermore, while physicians "belonged to one profession, they did not belong to the same social class" (ibid., p. 243).

162 Ross, op. cit., note 34 above. Ross would later write "That the men who render the greatest service to the world should receive at least some of the good things ..." which the world provides to those less worthy. [Unsigned attributed to Ross] in 'Public gratitude for scientific achievement', Sci. Prog., 1925, 19: 496.

163 Ross, op. cit., note 37 above.

164 Ross, op. cit., note 1 above, p. 516.

165 Ross, op. cit., note 147 above, p. 317.

166 J. Z. Bowers, 'The odyssey of smallpox vaccination', Bull. Hist. Med., 1981, 55: 17-33.
} 


\section{Eli Chernin}

approved his petitions as much for reasons of Britain's public and international image as to benefit Jenner's enfeebled purse.

By contrast, malaria never caused widespread deaths in Britain, and by Ross's time it had all but disappeared from the islands. ${ }^{167}$ Malaria was then, as now, a major cause of morbidity and mortality in the tropics, but the disease did not approach in impact the depredations of smallpox. Ross's discovery gave direction to malaria control and insight into the arthropod transmission of disease. But the social and political circumstances of Britain in 1900 were not those of 1800 , malaria was not smallpox, and - in Ross's own instructive words - his malaria research was "much humbler work" than Jenner's. ${ }^{168}$

Ross may have been perceived as one who stirred up public opinion to his own advantage. He had garnered the unanimous support of the BMA for his petition to Parliament, he was usually backed by the upper stratum of British institutional medicine, and in consequence of his public pressures and private politicking he gained the attention of the highest figures in government. In the event, however, Ross's petitions and other schemes failed, and the Great Depression froze any possibility of improved emoluments for medical scientists until after World War II. It must be noted, however, that Ross wove his pecuniary campaigns into a fabric of other changes he sought: better quality and less Babbittry in science, expanded teaching of science in the schools, and improvement in the quality of scientific publications. ${ }^{169}$

Ross was a versatile character. His place is secure in the history of medical science, and his quantitive epidemiology ("pathometry") is still being elaborated upon; ${ }^{170}$ his literary works stand in need of critical reappraisal, and he merits a definitive biography. His biographer will not lack material; on the contrary, he may find an excess of it, considering the diversity of Ross's undertakings and the care with which he saved every scrap of paper for his bulging archives. We do have Ross's own Memoirs, ${ }^{171}$ which bear mainly on his malaria work, and a peculiar "biography" by Mégroz. ${ }^{172}$ Ross seems to have suffered from a surfeit of talent, from a determination to be brilliant, and from a lack of humility, which together may have provided him with the stuff of deep-seated insecurity. Harrison assessed Ross, accurately, I think, as "a complicated and chronically maladjusted man ... one who viewed life as a struggle and himself as a soldier perpetually in battle with people and forces that sought, from stupidity and maliciousness, to frustrate him and hold back the course of human progress."173

Ross's successful work on malaria in India and his unsuccessful pursuit of remuneration in Britain required sustained efforts. His strong sense of personal entitlement reflected the attitude that was endemic among Victorian and later

${ }^{167}$ L. J. Bruce-Chwatt and J. de Zulueta. The rise and fall of malaria in Europe, Oxford University Press, 1980, pp. 131-145.

168 Ross, op. cit., note 1 above, p. 516.

169 [Unsigned; attributed to Ross], 'Great science and little science', Sci. Prog., 1916, 10: 658; and 'Scientific periodicals', ibid., 1925, 20: 286-287.

$170 \mathrm{~J}$. Needleman, 'Some new thoughts about some old malaria models', Math. Biosci., 1985, 73: $159-182$.

171 Ross, op. cit., note 1 above.

172 Mégroz, op. cit., note 153 above.

173 Harrison, op. cit., note 1 above, p. 7. 
practitioners: that the ultimate mark of status in the profession was wealth. ${ }^{174}$ If Ross's quest for money is a commentary on the man, it is also a commentary on a society that had not yet learned the value of science and was not much inclined to reward excellence in research. Perhaps Ross should have the last word: "History tells us that the reapers in science are many - but the sowers few. The only honest way to encourage discovery is to pay the men who achieve it."175,176

\section{ACKNOWLEDGEMENTS}

I am indebted: to Mary E. Gibson, Assistant Librarian, London School of Hygiene and Tropical Medicine, for generous advice and for her scholarly Catalogue of the Ross Archives; to Professor David J. Bradley, Director of the Ross Institute in the London School, for his kind permission to study and publish materials from the Ross Archives; to Richard J. Wolfe, Curator of Rare Books, Countway Library of Medicine, Harvard Medical School, Boston, for helpful discussions; to many colleagues on both sides of the Atlantic who favoured me with views and information; and to the journal's anonymous reviewers for their thoughtful commentaries. This study was supported, in part, by a Research Career Award for the National Institutes of Health, Bethesda, Maryland, and by a grant from the Milton Fund of Harvard University. The paper is dedicated, in memoriam, to M.S.C.

174 Peterson, op. cit., note 5 above, pp. 215, 222-224.

175 R. Ross, 'The encouragement of discovery - a proconnary.' Sci. Prog., 1924, 19: 306.

176 In broad terms, the rewards of research, as measured by monetary return, are complex and inevitably inconsistent. Edward Jenner asks Parliament and receives, but William Morton (ether) asks Congress and fails; Frederick Banting (insulin) receives - unasked - from Canada, but his contemporary Ronald Ross asks Britain and fails. For Jenner, see Baron, op. cit., note 39 above; for Morton, see J. F. Fulton, 'William Thomas Green Morton', in D. Malone (editor), Dictionary of American biography, New York, Scribners, 1934, 3: 268-271; for Banting, see M. Bliss, The discovery of insulin, University of Chicago Press, 1982, pp. 220-222. For sociological studies on the rewards of scientific research, see for example, R. K. Merton, The sociology of science, ed. N. W. Storer, University of Chicago Press, 1973, pp. 286-412; J. Gaston, The reward system in British and American science, New York, John Wiley, 1978. The sociologists tend not to consider monetary reward except narrowly as salary. Money is, however, a central and perhaps overriding reward of present-day biotechnological research aimed at developing marketable products. 